\title{
Familial occurrence of the antiphospholipid syndrome
}

\author{
F MATTHEY, K WALSHE, I J MACKIE, S J MACHIN \\ From the Department of Haematology, Middlesex Hospital, London
}

SUMMARY In a family of four the whole spectrum of antiphospholipid and associated antibodies was present but without evidence of connective tissue disease. All four members had anticardiolipin antibodies; two had a confirmed lupus anticoagulant. Thrombocytopenia was severe in one and associated with a high titre of antiplatelet antibody, while another member was found to have a positive antiglobulin test. One member also had a low protein $\mathrm{C}$ concentration while two had decreased concentration of protein $\mathrm{S}$.

Factors that predispose to these antibodies may be environmental as well as genetic. In view of the well known association of spontaneous thrombotic events with some of these antibodies the prognosis for the family members must be guarded.

The term "antiphospholipid syndrome" has been proposed to describe the association of arterial and venous thrombosis, recurrent fetal loss, and immune thrombocytopenia with a spectrum of autoantibodies directed against cellular phospholipid components. ${ }^{1}$ Anticardiolipin antibodies (ACA) may react with cardiolipin and with other negatively charged phospholipids, while the term lupus anticoagulant refers to a heterogeneous group of antibodies, most commonly of the IgG type, that are detected by their inhibitory effect on coagulant-active phospholipid components of in vitro coagulation tests. Such "anticoagulants" may occur in various connective tissue and other disorders and also in some patients without any underlying disease.

In this paper we describe a family in which the full spectrum of antiphospholipid and associated antibodies are present and in which none of the members seemed to have any clinical or serological evidence of connective tissue disease.

\section{Patients and methods}

A four year old girl presented with a six month history of purpura. The peripheral platelet count varied from 25 to $40 \times 10^{9} / 1$ and immune thrombocytopenia was diagnosed after a bone marrow aspirate showed numerous megakaryocytes. Her twin brother also had a history of a tendency for easy bruising, and the mother had previously been investigated for chronic mild anaemia related to a positive direct antiglobulin test. The mother had never had any spontaneous abortions and both she and the father were clinically well. The marriage was non-consanguineous.

Accepted for publication 1 December 1988
Blood was collected into plain glass tubes for serum preparation for ACA assays, or $0 \cdot 106 \mathrm{M}$ trisodium citrate ( 9 volumes blood to 1 volume anticoagulant) for coagulation tests. Plasma was obtained by centrifugation at $2000 \mathrm{~g}$ for 15 minutes, and for the dilute Russell's viper venom time, an aliquot of the plasma was placed in a plastic tube and centrifuged again using the same conditions, thus ensuring maximum removal of residual contaminating platelets.

Thrombin times and prothrombin times were performed by standard techniques. ${ }^{2}$ Activated partial thromboplastin times (APTT) were performed as a screening test for lupus anticoagulants and other haemostatic defects using a 10 minute incubation period $^{3}$ and were assessed on control and test plasmas as well as on a 50/50 mixture of the two. All samples were further tested using a more specific technique to detect the presence of a lupus anticoagulant.

DILUTE RUSSELL'S VIPER VENOM TIME (DRVT)

To confirm the presence of a lupus anticoagulant the dilute Russell's viper venom time ${ }^{4}$ was assessed. This was performed with certain modifications ${ }^{5}$ using both platelet substitute (Diagnostic Reagents Ltd, Thame, Oxfordshire) and freeze-thawed, lysed washed normal platelets as the source of phospholipid. Patients were defined as lupus anticoagulant positive when the ratio of their dilute Russell's viper venom time to that of normal control plasma with phospholipid reagent was greater than 1.06, but which decreased when lysed washed platelets were substituted as the phospholipid source.

ANTICARDIOLIPIN ACTIVITY

Anticardiolipin assays were performed by ELISA $^{6}$ and 
standardised using reference sera (The Lupus Research Laboratory, Rayne Institute, St Thomas's Hospital, London), calibrated by an international workshop.?

\section{PROTEIN C}

An amidolytic assay for protein $\mathrm{C}$ was performed using Copperhead snake venom (Protac C) and a chromogenic peptide substrate (2 AcOH-H-D-Lys (cbo) Pro-Arg-pNA) (Pentapharm Ltd, Basle, Switzerland). Protein $C$ antigen titres were measured by an ELISA using a polyclonal antiserum (Dako Ltd, High Wycombe, Buckinghamshire). ${ }^{8}$

\section{PROTEIN S}

Protein $\mathrm{S}$ was measured by electroimmunoassay with polyclonal antiserum (Dako Ltd) (modified from Comp et al ${ }^{9}$ ). Protein S was assayed with and without treatment of the plasma with $25 \%$ polyethylene glycol 6000 (total and free protein S), so that the protein complexed with $\mathrm{c} 4 \mathrm{~b}$-binding protein and free circulating forms were assessed.

\section{PLATELET AGGREGATION}

Platelet aggregation studies ${ }^{8}$ were performed with a Payton 300BD aggregometer (Centronic Sales Ltd, New Addington, Croydon), using a range of doses of agonists (adenosine diphosphate, collagen, ristocetin). Antiplatelet antibodies were estimated with an enzyme linked immunoassay technique. ${ }^{10}$

\section{FACTOR VIII AND VON WILLEBRAND FACTOR ASSAYS}

Factor VIII was measured by one stage coagulation assay using immune depleted plasma as substrate (Diagnostic Reagents Ltd), and the British Standard (NIBSC, South Mimms, Hertfordshire). Von Willebrand factor antigen was measured by an ELISA technique ${ }^{11}$ using polyclonal antisera (Dako Ltd), and ristocetin cofactor assays were performed by a modified platelet aggregometry technique, ${ }^{12}$ using fresh washed platelets. The latter two assays were standardised using the blood coagulation factor standard (NIBSC).

\section{Results}

All family members had a normal thrombin time, prothrombin time, platelet aggregation, factor VIII and von Willebrand factor. Screens for autoantibodies (including anti-nuclear and anti-double stranded DNA antibodies) were negative throughout. The results of the other haemostatic variables and antibody studies are shown in table 1 and protein $\mathrm{C}$ and protein $S$ values in table 2 .

The daughter with severe thrombocytopenia had considerably raised platelet-associated antibodies, a confirmed lupus anticoagulant as assessed by the dilute Russell's viper venom time, mildly increased IgG anticardiolipin antibody titre and low concentrations of protein $\mathrm{C}$ and protein $\mathrm{S}$ (tables 1 and 2). Her brother also had a positive dilute Russell's viper venom time, a moderately raised titre of IgG anticardiolipin, a normal protein $\mathrm{C}$ concentration, and a decreased protein $\mathrm{S}$ concentration. His platelet count was repeatedly mildly decreased, although he did not have a significant titre of antiplatelet antibodies. Similarly, the father had mild thrombocytopenia without raised antiplatelet antibodies but he, too, had an IgG anticardiolipin antibody. His prolonged APTT did not correct with the addition of normal plasma, but the result of the dilute Russell's viper venom time was equivocal and so a lupus anticoagulant was not confirmed. Finally, the mother had considerably raised IgG and mildly increased IgM anticardiolipin titres but no lupus anticoagulant. Her platelet count was normal but she was the only member of the family who gave a positive direct antiglobulin test. Protein C and $\mathbf{S}$ estimations were normal in both parents.

\section{Discussion}

Lupus anticoagulants and anticardiolipin antibodies are directed against cellular phospholipid moieties and comprise a wide range of autoantibodies found in the antiphospholipid syndrome. They often occur in the same person ${ }^{13}$ and may be associated with both arterial and venous thrombosis and with immune throm-

Table 1 Results of lupus anticoagulant studies, anticardiolipin assays, antiplatelet antibody assays and direct antiglobulin tests in family members

\begin{tabular}{|c|c|c|c|c|c|c|c|c|c|c|}
\hline \multirow[b]{2}{*}{ Family member } & \multicolumn{2}{|l|}{$A P T T$} & \multicolumn{2}{|c|}{$D R V T$} & \multicolumn{2}{|c|}{$\begin{array}{l}\text { Anticardiolipin } \\
\text { antibody }\end{array}$} & \multirow{2}{*}{$\begin{array}{l}\text { Platelet } \\
\text { count } \\
\left(\times 10^{9} \mathrm{l}\right)\end{array}$} & \multicolumn{2}{|c|}{$\begin{array}{l}\text { Antiplatelet } \\
\text { antibody }\end{array}$} & \multirow{2}{*}{$\begin{array}{l}\text { Direct } \\
\text { antibody } \\
\text { test }\end{array}$} \\
\hline & $\begin{array}{l}\text { Patient } \\
\text { (seconds) }\end{array}$ & $\begin{array}{l}50 / 50 \\
\text { mixture }\end{array}$ & $\begin{array}{l}P L S \\
\text { ratio }\end{array}$ & $L W P$ & $\begin{array}{l}\operatorname{IgG} \\
(G P L u)\end{array}$ & $\begin{array}{l}\operatorname{Ig} M \\
(M P L u)\end{array}$ & & $\begin{array}{l}\text { IgG } \\
(n g / 10\end{array}$ & $\begin{array}{l}\text { IgM } \\
\text { elets) }\end{array}$ & \\
\hline $\begin{array}{l}\text { Mother } \\
\text { Father } \\
\text { Son } \\
\text { Daughter } \\
\text { Normal range }\end{array}$ & 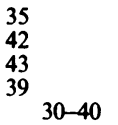 & $\begin{array}{l}35 \\
47 \\
43 \\
42\end{array}$ & $\begin{array}{r}0.87 \\
1 \cdot 12 \\
1 \cdot 17 \\
1.27 \\
0.8\end{array}$ & $\begin{array}{l}0.83 \\
1 \cdot 13 \\
1 \cdot 12 \\
1 \cdot 16 \\
06\end{array}$ & $\begin{array}{r}55.0 \\
26.5 \\
20.6 \\
8.2 \\
<\quad 5.0\end{array}$ & $\begin{array}{r}3.9 \\
2.6 \\
2.0 \\
2.1 \\
<3.0\end{array}$ & $\begin{array}{r}269 \\
150 \\
140 \\
30 \\
150-400\end{array}$ & $\begin{array}{c}1 \cdot 8 \\
6 \cdot 0 \\
4 \cdot 0 \\
23 \cdot 0 \\
2-10\end{array}$ & $\begin{array}{r}0.8 \\
3.1 \\
1.0 \\
64.0 \\
<\quad 2.5\end{array}$ & $\begin{array}{l}+\mathrm{IgG} \\
- \\
-\end{array}$ \\
\hline
\end{tabular}

PLS = Platelet substitute; LWP = Lysed washed platelets. 
Table 2 Results of protein $C$ and protein $S$ assays on family members

\begin{tabular}{llllll}
\hline & \multicolumn{2}{l}{$\begin{array}{l}\text { Amidolytic } \\
\text { protein C }\end{array}$} & & \multicolumn{2}{l}{$\begin{array}{l}\text { Percentage protein } \\
\text { Santigen }\end{array}$} \\
\cline { 2 - 3 } \cline { 5 - 6 } \cline { 5 - 6 } \cline { 5 - 6 } & Chromogenic & Antigenic & & Total & Free \\
\hline Mother & $0.98 \mathrm{U} / \mathrm{ml}$ & Not done & & 110 & 71 \\
Father & $1.05 \mathrm{U} / \mathrm{ml}$ & Not done & & 101 & 84 \\
Son & $0.78 \mathrm{U} / \mathrm{ml}$ & $0.82 \mathrm{U} / \mathrm{ml}$ & & 56 & 50 \\
Daughter & $0.58 \mathrm{U} / \mathrm{ml}$ & $0.52 \mathrm{U} / \mathrm{ml}$ & & 70 & 65 \\
Normal range & $0.7-1.2 \mathrm{U} / \mathrm{ml}$ & & $90-147$ & $76-120$ \\
\hline
\end{tabular}

bocytopenia in connective tissue diseases.$^{14} \mathrm{It}$ has been postulated that these antibodies may cross react with phospholipid components of the platelet membrane, thereby mediating their immune destruction. Indeed, moderate reduction of the platelet count has been found to be a risk factor for thrombosis in patients with lupus anticoagulant. ${ }^{15}$ Furthermore, abnormalities of protein $\mathrm{C}$ activation have been recorded in association with antiphospholipid antibodies ${ }^{16}$ as well as the presence of a positive direct antiglobulin test. ${ }^{17}$

The occurrence of lupus anticoagulant and ACA within families has been recorded only rarely. ${ }^{518}$ In these reports the index cases had diagnosed systemic lupus erythematosus or related immune disorders while many of their family members had a variety of clinical or serological features suggestive of a lupuslike syndrome.

All the members of the family studied in this paper had one or more serological features of the antiphospholipid syndrome, while three of them had an associated clinical feature, although none had any clinical evidence of a connective tissue disorder. Thus the whole family had raised ACA titres while the two children had a confirmed lupus anticoagulant. The daughter originally presented with thrombocytopenic purpura and her brother and father were subsequently found to have mild asymptomatic thrombocytopenia as well. Although not strictly part of the syndrome, it is interesting that the children had low protein $\mathrm{C}$ or protein $\mathrm{S}$ concentrations, or both, while the mother had a positive antiglobulin test.

The different profile of coagulation tests and antibody results for each member of the family may reflect different stages of an autoimmune process, or merely a different antibody response to similar stimuli. We have previously suggested that there may be a transmissible agent or other environmental factor involved in the pathogenesis of these antibodies as well as discrete genetic susceptibility factors, ${ }^{5}$ and the range of results found in this family would support this. Alternatively, the lupus anticoagulant may just be an epiphenomenon in many patients and may arise following cellular activation and membrane damage. Clearly, it is advisable to screen for other known causes of recurrent thrombosis in patients who possess a lupus anticoagulant. The likelihood of future com- plications occurring in members of this family is unclear. There are as yet no prospective studies to assess the risk of thrombosis in patients with lupus anticoagulant who are asymptomatic, although retrospective analyses suggest this is to be about $30 \%,{ }^{15}$ Regular follow up of the family is required to ensure prompt management of any clinical complications that may develop in the future.

References

1 Harris EN. Syndrome of the black swan. $B r J$ Rheumatol 1987;26:324-6.

2 Austin DEG, Rhymes IL. In: A laboratory manual of blood coagulation. Oxford: Blackwell Scientific Publications, 1976.

3 Hardisty RM, Ingram GIC. In: Bleeding disorders-investigation and management. Oxford: Blackwell Scientific Publications, 1965.

4 Thiagarajan P, Pengo V, Shapiro SS. The use of the dilute Russell's viper venom time for the diagnosis of lupus anticoagulants. Blood 1986;68:869-74.

5 Mackie IJ, Colaco CB, Machin SJ. Familial lupus anticoagulants. Br J Haematol 1987;67:359-63.

6 Loizou S, McRea JD, Rudge AC, Reynolds R, Boyle C, Harris EN. Measurement of anti-cardiolipin antibodies by an enzymelinked immunosorbent assay (ELISA): standardization and quantitation of results. Clin Exp Immunol 1985;62:738-45.

7 Harris EN, Gharavi AE, Patel SP, Hughes GRV. Evaluation of the anti-cardiolipin antibody test: report of an international workshop held 4th April 1986. Clin Exp Immunol 1987;68: 215-22.

8 Mackie IJ, Machin SJ. Haemostasis. In: Chanarin I, ed. Laboratory haematology. Churchill Livingstone: 1989.

9 Comp PC, Doray D, Patton D, Esmon LT. An abnormal distribution of protein $\mathbf{S}$ occurs in functional protein $S$ deficiency. Blood 1986;67:504-8.

10 Hegde UM, Ball S, Zuiable A, Roter BLT. Platelet associated immunoglobulins (PAIgG and PAIgM) in autoimmune thrombocytopenia. Br J Haematol 1985;59:221-6.

11 Short PE, Williams CE, Picken AM, Hill FG. Factor VIII related antigen: an improved enzyme immunoassay. Med Lab Sci 1982;39:351-5.

12 Macfarlane DE, Stibbe J, Kirby EP, Zucker MB, Grant RA, McPherson J. A method for assaying von Willebrand factor (ristocetin cofactor). Throm Diath Haem 1975;34:306.

13 Harris EN, Gharavi AE, Boey ML, et al. Anticardiolipin antibodies: detection by radioimmunoassay and association with thrombosis in systemic lupus erythematosus. Lancet 1983; ii: 1211-14.

14 Harris EN, Asherson RA, Gharavi AE, Morgan SH, Derue G, Hughes GRV. Thrombocytopenia in SLE and related immune disorders: association with anticardiolipin antibody. $B r J$ Haematol 1985;59:227-30.

15 Lechner K, Pabinger-Fasching I. Lupus anticoagulants and thrombosis. A study of 25 cases and review of the literature. Haemostasis 1985;15:254-62.

16 Cariou R, Tobelem G, Soria C, Caen J. Inhibition of protein C activation by endothelial cells in the presence of lupus anticoagulant. $N$ Engl J Med 1986;314:1193-4.

17 Schleider MA, Nachman RL, Jaffe EA, Coleman M. A clinical study of the lupus anticoagulant. Blood 1976;48:499-509.

18 Exner T, Barber S, Kronenberg H, Rickard KA. Familial association of the lupus anticoagulant. Br J Haematol 1980; 45:89-96.

Requests for reprints to: Dr F Matthey, Department of Haematology, Middlesex Hospital, Mortimer Street, London WIN 8AA, England. 